open all examinations to the presence of every member of the profession. It is an utter waste of time and of money to be inspecting the recognised examinations when there are examinations of which the Council knows nothing and of which the public knows nothing - private special examinations, backdoors by which the black sheep of the flock can readily enter into the professional fold after they have been ignominiously rejected at the front door. It is absurd to be watching the front door while a back one is left open. I entreat your artention, Sirs, to this matter. Neither you nor the Council have the faintest suspicion of the abuses which flourish under it.

Cashel, Jan. 7th, 1895.

I am, Sirs, yours truly, THOMAS LAFHAN,

\section{THE TREATMENT OF EPILEPSY.} To the Editors of THE LANCET.

SIRS,-My attention has but recently been directed to the report in THW LANCET of Jan. 12th, of the meeting of the West London Medico-Chirurgical Society of Jan. 4th. I find I am therein represented as "referring to the benefits following the "tarvation treatment" of epilepsy (following the President in my nse of this term). So far as I am concerned I am anxious to disavow the expression of such a view, my experience being that adequate nutrition is an essential to successful treatment. The view I adrocated was, in truth, the utility of the substitution of an ample milk diet for one containing meat, for which, I submit, the designation of "starvation diet" is a misnomer. In my opinion advantage is derived, not only from the restriction of nitrogenous slements, which (according to some authorities) tend to the formation of unstable compounds in the nervous tissue farouring discharging lesions in the epileptic, but also from the aroidance of digestive troubles so often exciting an attack. In children especially, untrained in the Gladstonian method of mastication, who bolt imperfectly chewed masse of meat, the gain of a milk diet is great, as I had proof amongst the epileptic inmates of the Royal Albert Asylum, of which I was till lately medical superintendent. But the diet consisting of bread and milk, oatmeal porridge, farinaceous and custard puddings, with an ample supply of milk and eggs, was in no sense "starvation diet," the body weight usually increasing under the regimen. The discharging lesion of epilepsy appears, indeed, to depend apon nutrition being defective, not in quantity, but in quality; and Dr. Hughlings Jackson suggested long ago that "in the abnormal nutritive process producing unstable matter, nervons matter, the phosphorous ingredient is replaced by its shemical congener nitrogen." As regards drug treatment, borax in some cases seems to "act as a charm," bat how to differentiate these cases is the difficulty. Regulated muscular exercise, especially in the open air ( $d \mathrm{~s}$ in garden work), has, in my experience, been of more effisacy than drugs.

I am, Sirs, yours faithfully,

Lichmond, Surrey, Jan. 22nd, 1895.

\section{THE LATE SURGEON-MAJOR PARKE.}

\section{To the Editors of THE LANCET.}

SIRS,-As Provincial Deputy Grand Master of the Freemasons of North Connanght I would wish through your 3. Jamns to inform those members of the profession who belong to the order that the Memorial Masonic Hall to be erected in Carrick-on-Shannon, the native town of the late deeply lamented Surgeon-Major Parke, has not as yet been commenced owing to the funds sollected being insufficient for the purpose. I feel certain ihat every member of the medical profession would wish the vame of one whose services botb in the field and with the Emin Pasha Relief Expedition were so distinguished should be permanently kept in memory, and this being distinctively 3 Uasonic memorial I would ask physicians and surgeons being Freemasons to contribute. Small donations will be thankfully received, and may be sent to me or to SurgeonLieutenant-Colonel Bradshaw, Carrick-on-Shannon. Further lists of subscribers will be published, and all subscripions daly acknowledged.

$$
\text { I am, Birs, yours faithfully, }
$$
Francis k. ClaRKe, M.D., M.R.C.P.I.

Eogle, Ireiand, Jan. 17th, 1895.
PROPOSED ASSOCIATION OF QUALIFIED MEDICAL ASSISTANTS, JUNIOR MEDICAL OFEICERS, AND LOCUMTENENTS.

To the Editors of THE LANCET.

SrRs,- - It has occurred to me that such an association as the one proposed would be found to be very advantageous to gentlemen filling above appointments, and with this object in view I venture to state briefly some of the questions which might be settled by such a powerful organisation as this association might in time become if properly and rightly managed :-1. In connexion with this association I would suggest the formation of a special department, styled the "Medical Bureau," to take the place of the present private medical agencies, whereby members of this association might, by subscription or otherwise, possess the means at reasonable charges for obtaining suitable appointments.

2. The question of salaries paid to qualified assistants : $(a)$ mode of treatment by principal or committee; $(b)$ terms of engagement and dismissal; $(c)$ contracts or covenants not to practise. 3. The "social" status of the qualified assistant should be fairly recognised as a legally appointed medical man. 4. Discontinuance of employment of unqualified men as medical assistants, and the results therefrom: (a) more openings for the qualified man; (b) therefore less needy men in our ranks ready to jump at any poorly paid office $;(c)$ in every town where there are sufficient qualified chemists I would suggest that every practitioner should employ such to dispense his medicine; $(d)$ such a plan as this would leave a field of labour open to the unqualified assistant, as his services might be used by chemists ; $(e)$ and in case medical men ceased to countenance or even employ unqualified men, then chemists should be compelled to give up prescribing as they do now. 5 I further think as a sound basis such an association should possess some code of ethics, so that each new man in the profession should become intimately acquainted with the true meaning of medical etiquette, which to my mind is the ground-work of all real proper feeling and treatment of one medical man to another. And, lastly, if these matters were carried out I venture to think in time we should gradually find our profession would take its proper and legitimate position in the world as a truly scientific calling, and not as the miserable trade which many make it.

I am, Sirs, yours truly,

T. HowaRd BRocklehURST, M.R.C.S. Eng., L.S.A. Lond. Westham, Weymouth, Jan. 23rd, 1895.

$*_{*}^{*}$ It will be noticed that we have adopted Dr. Donkin's suggestion (vide THE L.ANCET, Jan. 12th, p. 120) with regard to a practical "plural of locum tenens."-ED. L.

\section{'LHE ASCULAPIUS LODGE.}

To the Editors of THE LANCEn.

SIRs,-Gladly as would be welcomed amongst all good Masons any lodge bringing closer together members of the profession, I venture to suggest that the lodge in process of formation in connexion with St. Bartholomew's Hospital, as reported in THE LANCET, cannot be beld to be quite on parallel lines with those of the three universities-Oxford, Cambridge, and London-or even with the Bar Lodge. The claim to such a distinction rests with the सisculapius Lodge, now in its fourth year of existence, since we number not only members of a particular hospital, but of the whole medical profession wherever educated throughout the British Empire.-I am, Sirs, your obedient servant, Portland-place, W.,
Jan. 19th, 1895.

ThOMAS DUTTON, Secretary, Assculapius Lodge.

\section{"THE SUPPORT OF HOSPITALS." \\ To the Editors of THE LANCET.}

SIRs,-With reference to an annotation which appeared in THE LANCET of Jan. 12th, dealing with the financial condition of our hospitals and taking the case of Charingcross as a text, I should like to make a few remarks.

It is especially of importance that those interested in the immediate working of a hospital should look most carefully into every detail of its management and see that its claims 